\title{
Bacteria and yeasts associated to Colonial cheese production chain and assessment of their hydrolytic potential
}

\section{Bactérias e leveduras associadas às etapas de produção de queijo Colonial e avaliação de seu potencial enzimático}

\author{
Priscilla Vieira de Souza ${ }^{1}$, Cristina B. Zaffari Grecellé2 ${ }^{2}$, Fabiano Barreto ${ }^{3}$, \\ Maurício Ramírez-Castrillon ${ }^{4}$, Patrícia Valente ${ }^{5}$, Marisa da Costa ${ }^{5 *}$ (i)
}

${ }^{1}$ Universidade Federal do Rio Grande do Sul (UFRGS), Programa de Pós-graduação em Microbiologia Agrícola e do Ambiente, Porto Alegre/RS - Brasil

${ }^{2}$ Universidade Luterana do Brasil (ULBRA), Faculdade de Veterinária, Canoas/RS - Brasil

${ }^{3}$ Ministério da Agricultura Pecuária e Abastecimento, Laboratório Federal de Defesa Agropecuária/RS, Porto

Alegre/RS - Brasil

${ }^{4}$ Universidad Santiago de Cali, Facultad de Ciencias Básicas, Research Group in Mycology, Cali - Colombia

${ }^{5}$ Universidade Federal do Rio Grande do Sul (UFRGS), Instituto de Ciências Básicas da Saúde (ICBS),

Departamento de Microbiologia, Imunologia e Parasitologia, Porto Alegre/RS - Brasil

*Corresponding Author: Marisa da Costa, Universidade Federal do Rio Grande do Sul (UFRGS), Instituto de Ciências Básicas da Saúde (ICBS), Departamento de Microbiologia, Imunologia e Parasitologia, Rua Sarmento Leite, 500, Sala 216, Prédio ICBS, Campus Reitoria, CEP: 90050-170, Porto Alegre/RS - Brasil, e-mail: mdcosta@ufrgs.br

Cite as: Souza, P. V., Grecellé, C. B. Z., Barreto, F., Ramírez-Castrillon, M., Valente, P., \& Costa, M. (2021).

Bacteria and yeasts associated to colonial cheese production chain and assessment of their hydrolytic potential.

Brazilian Journal of Food Technology, 24, e2020286. https://doi.org/10.1590/1981-6723.28620

\begin{abstract}
Different types of microorganisms are important in cheese-making because of the contributions their metabolism offers during the process. Few microorganisms present in Colonial cheese are known, in addition to the ones that are introduced to kick-start the processes or the ones that are associated with infections or poisonings. This study aimed to identify, by MALDI-TOF and/or DNA sequencing, the bacteria and yeasts isolated from samples collected in the main stages of Colonial cheese production, i.e., a type of cheese produced in the southern region of Brazil. The lytic capacity of these microorganisms at $5{ }^{\circ} \mathrm{C}$ and $30{ }^{\circ} \mathrm{C}$ was also evaluated. The 58 bacterial strains were distributed in 10 species among the genera Bacillus, Citrobacter, Klebsiella, Lactococcus, Paenibacillus, Staphylococcus and Raoutella. From the 13 yeasts strains analyzed, three species were identified as following: Candida pararugosa; Meyerozyma guilliermondii; and Rhodotorula mucilaginosa. In three yeasts isolates it was possible to identify only the genus Candida sp. and Trichosporon sp. The species L. lactis (48\%) and M. guilliermondii $(46 \%)$ were, respectively, the predominant bacteria and yeasts species isolated. The highest microbial lytic activity observed was at $30^{\circ} \mathrm{C}$. Lipase activity on isolates was proportionally more observed with yeasts and proteolytic activity with bacteria. Lower caseinase and lipase activity was observed at $5{ }^{\circ} \mathrm{C}$, demonstrating the importance of refrigeration in controlling microbial activity. This research highlighted the cultivation of some microorganisms that are part of the Colonial cheese microbiota as well as that several of them can hydrolyze various compounds present
\end{abstract}


in milk and that could be associated with its maturation or, in uncontrolled circumstances, could be the cause of product deterioration.

Keywords: Microbiota; Enzymes; Proteolytic activity; Lipolytic activity; Agro-industries; MALDI-TOF.

\section{Resumo}

Durante o processo de produção do queijo, é necessária a presença de diversos microrganismos que contribuem na sua elaboração pela ação de seu metabolismo. Pouco é conhecido sobre os microrganismos presentes no queijo Colonial, além daqueles inseridos para iniciar o processo ou daqueles indesejados, potenciais causadores de infecção ou intoxicação. Este trabalho teve como objetivo principal identificar, através de MALDI-TOF e/ou sequenciamento de DNA, bactérias e leveduras isoladas de amostras coletadas nas principais etapas de produção de queijo Colonial, um tipo de queijo produzido na Região Sul do Brasil. Também foi verificada a capacidade lítica destes microrganismos a $5{ }^{\circ} \mathrm{C}$ e $30^{\circ} \mathrm{C}$. Foram analisados 58 isolados de bactérias, sendo identificadas 10 espécies de bactérias distribuídas nos gêneros Bacillus, Lactococcus, Paenibacillus, Staphylococcus, Citrobacter, Klebsiella e Raoutella. Dos 13 isolados de leveduras, foram identificadas três espécies: Candida pararugosa, Meyerozyma guilliermondii e Rhodotorula mucilaginosa. Em três isolados de leveduras, foi possível a identificação somente dos gêneros Candida sp. e Trichosporon sp. As espécies Lactococcus lactis (48\%) e M. guilliermondii (46\%) foram os isolados predominantes de bactéria e levedura, respectivamente. A maior atividade lítica dos microrganismos identificados foi na temperatura de $30{ }^{\circ} \mathrm{C}$. Proporcionalmente, foi verificado maior número de isolados com atividade de lipase pelas leveduras e maior atividade proteolítica pelas bactérias. Menor atividade de caseínase e lipase foi observada a $5{ }^{\circ} \mathrm{C}$, demonstrando a importância da refrigeração no controle da atividade microbiana. Este trabalho mostrou, através de cultivo, alguns dos microrganismos que fazem parte da microbiota do queijo Colonial e que vários deles possuem capacidade de hidrolisar vários compostos presentes no leite. Mostrou também que podem estar associados com a maturação do mesmo ou, em circunstâncias não controladas, que poderiam ser a causa de deterioração do produto.

Palavras-chave: Microbiota; Enzimas; Atividade proteolítica; Atividade lipolítica; Agroindústrias; MALDI-TOF.

\section{Introduction}

Colonial cheese is a variety of cheese produced by family cheese-making agro-industries in southern Brazil. This cheese is produced with raw or pasteurized bovine milk added to commercial cultures, curd salting and a maturation period of at least 20 days. The microbiota in cheeses is largely variable, and depends on seasonality, animal feeding, environment, milk microbiota and processing (heat treatment, type of cheese, equipment, and hygiene) (Tilocca et al., 2020). Microbial diversity in cheeses is necessary to obtain the sensory characteristics and desirable textures specific to each variety (Montel et al., 2014). Those sensory characteristics are the result of many factors, depending on the milk quality, which is influenced by the animal's breed, breeding conditions, kind of feed, soil composition, microbial load, etc.; and by the activity of milk enzymes and microbial metabolism (Milani et al., 2019). It was also observed that some cheese bacteria can transiently colonize the human gut in cheese consumers, providing a benefit through their enzymatic activities (Robinson et al., 2021; Milani et al., 2019; Zheng et al., 2015). Some of the benefits observed for occasional milk or cheese consumers were the increase in lipid excretion and the decrease in blood cholesterol levels; however, it has not yet been established whether this is correlated to a specific microorganism (Robinson et al., 2021; Zheng et al., 2015). Although the microbial composition of cheeses can influence a multitude of factors, almost nothing is known about the microorganisms present in Colonial cheese, except for its main contributors (such as Lactic Acid Bacteria (LAB)) or its potential pathogens (Funck et al., 2015; Pereira et al., 2017; Jonnala et al., 2018; Ausani et al., 2019; Carvalho et al., 2019; Pegoraro et al., 2020). Further information can assist in identifying the product regarding probiotic characteristics and potential, and determining the geographic origin and/or the qualification of a regional cheese.

This research aimed to identify a total of 71 strains of bacteria and yeast isolated throughout Colonial cheese manufacturing process as well as characterize their abilities to grow and produce specific enzymes at $30{ }^{\circ} \mathrm{C}$ and $5{ }^{\circ} \mathrm{C}$. 


\section{Material and methods}

All strains (71) were isolated in a previous study (Grecellé et al., 2020) in which the microbial quality of two Colonial cheese family agro-industries were evaluated. Both agro-industries were inspected by a regional official agency and produced an average of $370 \mathrm{~kg}$ of cheese per day. These cheeses are made from pasteurized milk with an added commercial starter (LAB). All Colonial cheese samples had the expected standard characteristics, of texture and flavor, at the time of analysis. The isolates were obtained from counting of aerobic mesophilic bacteria and molds from raw milk, curd, ripening cheese, and ready-to-eat cheese. Each different colony morphotype of bacteria and yeasts were selected and stored in Brain Heart Infusion (BHI) broth with $30 \%$ glycerol at $-20{ }^{\circ} \mathrm{C}$. To perform the identification, all isolates were restored first in BHI broth at $30{ }^{\circ} \mathrm{C}$ for $24 \mathrm{~h}$ and were later isolated on solid media (Plating counting agar for bacterial strains and/or GYP agar [glucose $2 \%$, peptone $1 \%$, yeast extract $0.5 \%$, agar $2 \%$ ] for yeast), twice to check purity, before identification procedures.

All isolates were tested for cell characteristics (Gram stain) and colonial morphology before using MatrixAssisted Laser Desorption/Ionization - Time-of-Flight Mass Spectrometry (MALDI-TOF MS) procedure and/or DNA sequencing. For the MALDI-TOF MS identification, protein extraction was performed according to previous studies (Bruker, 2015) and the cutoff used for characterization was proposed by Wieser et al. (2012), where scores values above 2.0 were considered for species level identification and values between 2.0 and 1.7 were reliable for genus level. Isolates not identified by MALDI-TOF MS were thus identified by sequencing.

Bacterial DNA extraction was performed after thermal extraction exactly as described by Riyaz-Ul-Hassan et al. (2008). Yeast DNA extraction was performed after pure colonies of each strain were grown in Glucose-YeastPeptone (GYP) broth at $30^{\circ} \mathrm{C}$ for 18 hours. After centrifugation and washing with distilled water, the biomass of each culture was re-suspended in $400 \mu \mathrm{L}$ of lysis buffer $(0.5 \mathrm{M} \mathrm{NaCl}, 10 \mathrm{mM}$ EDTA, $2 \%$ SDS, $50 \mathrm{mM}$ Tris-HCl, $\mathrm{pH} 8$ ) and incubated for $60 \mathrm{~min}$ at $65^{\circ} \mathrm{C}$. The other steps were done as described in Osorio-Cadavid et al. (2009).

Bacterial DNA amplification and sequencing were performed using $515 \mathrm{~F}$ and $806 \mathrm{R}$ primers for the hypervariable gene V3-V4 of 16SRNA region specific for prokaryotic cells (Bates et al., 2011). The amplification conditions followed were those described by Franco et al. (2016). For yeast DNA amplification, the ITS1-5.8S-ITS2 region was amplified and sequenced with ITS1 and ITS4 primers (White et al. 1990). Amplification conditions were as follows: one initial cycle at $94{ }^{\circ} \mathrm{C}$ for $5 \mathrm{~min} ; 35$ cycles at $94{ }^{\circ} \mathrm{C}$ for $15 \mathrm{~s} ; 55^{\circ} \mathrm{C}$ for $45 \mathrm{~s} ; 72{ }^{\circ} \mathrm{C}$ for $90 \mathrm{~s}$; and a final extension cycle at $72{ }^{\circ} \mathrm{C}$ for $6 \mathrm{~min}$.

All Polymerase Chain Reaction (PCR) products were examined by electrophoresis on a $1.5 \%$ of agarose gel at $100 \mathrm{~V}$ for $45 \mathrm{~min}$ and stained with GelRed and visualized under UV light. Digital image capturing was done using the Geni2 gelDoc System (Syngene, Cambridge, UK) (Ramírez-Castrillón et al., 2014). Before sequencing, PCR products were purified using the PCR Clean-Up System purification kit (Promega Corporation, Madison, USA) and then quantified on the spectrophotometer (NanoDrop Lite Thermo Fischer Spectrophotometer). Finally, Sanger sequencing of the PCR products were outsourced at the Unidade de Análises Moleculares e de Proteinas (UAMP), from Hospital de Clínicas de Porto Alegre, edited, assembled, and compared with the sequences of strain types catalogued in the GenBank database. A similarity cutoff of $99 \%$ was used to identify the isolates according to taxonomic level.

Bacteria and yeasts were also cultivated at $\pm 5^{\circ} \mathrm{C}$ to detect psycrotrophilic strains and went through testing to observe their lipolytic and proteolytic activities at $30{ }^{\circ} \mathrm{C}$ and $\pm 5{ }^{\circ} \mathrm{C}$, performed within $48 \mathrm{~h}$ (BenGigirey et al., 2000). DNase (Himedia), lactose tryptone broth (Himedia), and Litmus Milk (Fluka) tests were also performed at $30^{\circ} \mathrm{C}$ and $\pm 5{ }^{\circ} \mathrm{C}$. These essays were repeated once when there was no growth or dubious results were observed on the first essay. Results were evaluated qualitatively as positive or negative. 


\section{Results and discussion}

A total of 58 bacterial (53 gram-positives and five gram-negatives), and 13 yeasts were isolated and identified after freezing recover (Table 1). A total of seven gram-positive and three gram-negative species were identified. Yeasts isolates were distributed in four genera and three species. Most isolates were identified by the MALDI-TOF MS, excluding one species of L. lactis and the Rhodotorula mucilaginosa isolate, which were identified by DNA sequencing. Three yeast isolates were identified only at genus level using MALDI-TOF. Their species definition could not be realized by biochemical identification because of their viability being lost in the testing process.

Table 1. Bacteria and yeasts isolates identified from samples of the main production stages of Colonial cheese.

\begin{tabular}{|c|c|c|c|c|}
\hline Identification $^{\mathrm{a}}$ & Milk & Curd & $\begin{array}{c}\text { Ripening } \\
\text { cheese }\end{array}$ & $\begin{array}{c}\text { Read-to-eat } \\
\text { cheese }\end{array}$ \\
\hline \multicolumn{5}{|l|}{ Gram-positive } \\
\hline Bacillus cereus & 1 & - & - & - \\
\hline Bacillus mycoides & 4 & 1 & - & - \\
\hline Lactococcus lactis & 5 & 10 & 5 & 8 \\
\hline Paenibacillus humicus & - & - & 3 & 2 \\
\hline Staphylococcus xylosus & - & 1 & - & - \\
\hline Staphylococcus saprophyticus & 1 & 2 & 1 & 3 \\
\hline Staphylococcus warneri & 1 & 2 & 3 & - \\
\hline \multicolumn{5}{|l|}{ Gram-negative } \\
\hline Citrobacter freundii & - & - & 1 & - \\
\hline Klebsiella variicola & - & - & - & 1 \\
\hline Raoutella ornithinolytica & 3 & - & - & - \\
\hline Total bacteria & 15 & 16 & 13 & 14 \\
\hline \multicolumn{5}{|l|}{ Yeasts } \\
\hline Meyerozyma guilliermondii & 4 & - & - & 2 \\
\hline Candida pararugosa & - & - & - & 3 \\
\hline Candida sp. & 1 & - & - & - \\
\hline Rhodotorula mucilaginosa & 1 & - & - & - \\
\hline Trichosporon sp. & 2 & - & - & - \\
\hline Total yeasts & 8 & $\mathbf{0}$ & $\mathbf{0}$ & 5 \\
\hline Total microorganisms & 23 & 16 & 13 & 19 \\
\hline
\end{tabular}

${ }^{a}$ Identification using MALDI-TOF MS for all isolates except $L$. lactis and $R$. mucilaginosa isolates that were identified by DNA sequencing.

More than $50 \%$ of the bacteria isolates were identified as L. lactis and they were isolated in all stages of the cheese manufacturing. This is unsurprising, because this species is commonly seen in the dairy industry environment; it is the starter bacteria used in the manufacture of various cheeses, as well as in Colonial cheeses, where it is the predominant species (Camargo et al., 2021; Kamimura et al., 2019; Peláez \& Requena, 2005; Leroy \& De Vuyst, 2004; El-Baradei et al., 2007; Ercolini et al., 2008). Kamimura et al. (2019) were also able to demonstrate that $L$. lactis was the most abundant species in various Brazilian cheeses using metagenomics. This species is important because it also prevents the growth of spoiling bacteria by acidifying the environment with lactose breakdown and by producing bacteriocins (Ávila et al., 2020; Bukvicki et al., 2020; Yang et al., 2019). Indeed, they are particularly needed for providing specific aromatic compounds. The majority of $L$. lactis isolates demonstrated a great ability do hydrolyze proteins and it was observed that approximately half of them had the ability to hydrolyze lactose at $30^{\circ} \mathrm{C}$, which is essential to the coagulation step (Table 2). A second species that was observed in all stages of cheese-making was $S$. saprophyticus, a common bacterium found in the microbiota of bovines, humans, and other warmed-blooded animals, as well as in their environment and in the cheese agro-industries (Schleifer, 2009; Grecellé et al., 2020). Approximately half of the S. saprophyticus and S. warnery isolates demonstrated the ability to hydrolyze proteins and lipids, and depending on its load, could facilitate cheese maturation or even hinder it. Three spore forming bacteria 
were isolated as following: two of them that had protease activity, Bacillus cereus and B. mycoides, were found on milk and curd; and the third species $P$. humicus was isolated from the cheese sample and had the ability to hydrolyze proteins and lactose. Of the three species, B. cereus is toxigenic and can cause food born intoxication depending on its cellular load. Whereas $P$. humicus is an environmental species that was described as capable of causing a blood infection (Berthold-Pluta et al., 2019; Sáez-Nieto et al., 2017). All the identified gram-negative species belonged to the Enterobateriaceae family, a bacterial family frequently observed in the local environment, as well as in some dairy facilities, and could indicate poor hygiene conditions (Pinto et al., 2015; Rodríguez-Medina et al., 2019; Hajjar et al., 2020; Jonnala et al., 2018). The Citrobacter sp., Klebsiella sp. and Raoutella sp., in addition to being opportunistic pathogens, are considered spoilage bacteria (Camargo et al., 2021; Teider Júnior et al., 2019; Jonnala et al., 2018). Although few isolates of gram-negative bacteria were identified, almost all demonstrated having the ability to hydrolyze proteins, lipids, and lactose. In Entre Serra and Minas Frescal cheeses, other regional Brazilian cheeses, C. freundii, L. lactis and Kelbsiella sp. were also isolated (Camargo et al., 2021; Teider Júnior et al., 2019).

Table 2. Enzymatic activity of bacteria and yeasts isolated from samples of the main production stages of Colonial cheese.

\begin{tabular}{|c|c|c|c|c|c|c|c|c|c|}
\hline \multirow{3}{*}{ Genus /Species } & \multirow{3}{*}{$\mathbf{N}^{\mathbf{o . a}}$} & \multicolumn{8}{|c|}{ Number of isolates with enzymatic activities } \\
\hline & & \multicolumn{2}{|c|}{ Proteinase } & \multicolumn{2}{|c|}{ Lipase } & \multicolumn{2}{|c|}{ Litmus Milk } & \multicolumn{2}{|c|}{ Lactose Ferm. $^{c}$} \\
\hline & & $30^{\circ} \mathbf{C}^{b}$ & $5^{\circ} \mathbf{C}^{b}$ & $30{ }^{\circ} \mathrm{C}$ & $5^{\circ} \mathrm{C}$ & $30{ }^{\circ} \mathrm{C}$ & $5^{\circ} \mathrm{C}$ & $30^{\circ} \mathrm{C}$ & $5^{\circ} \mathrm{C}$ \\
\hline \multicolumn{10}{|l|}{ Gram-positive } \\
\hline Bacillus mycoides & 5 & 5 & 1 & 3 & $-{ }^{\mathrm{d}}$ & 3 & - & - & - \\
\hline Bacillus cereus & 1 & 1 & - & - & - & - & - & - & - \\
\hline Lactococcus lactis & 28 & 24 & 3 & 11 & 5 & 10 & - & 5 & - \\
\hline $\begin{array}{c}\text { Paenibacillus } \\
\text { humicus }\end{array}$ & 5 & 2 & - & - & 1 & 3 & - & 2 & - \\
\hline $\begin{array}{l}\text { Staphylococcus } \\
\text { saprophyticus }\end{array}$ & 7 & 3 & 1 & 5 & 4 & 6 & - & - & - \\
\hline $\begin{array}{c}\text { Staphylococcus } \\
\text { warneri }\end{array}$ & 6 & 4 & 1 & 5 & 2 & 4 & - & - & - \\
\hline $\begin{array}{c}\text { Staphylococcus } \\
\text { xylosus } \\
\end{array}$ & 1 & 1 & - & - & - & - & - & - & - \\
\hline \multicolumn{10}{|l|}{ Gram-negative } \\
\hline Citrobacter freundii & 1 & 1 & - & - & - & - & - & 1 & - \\
\hline Klebsiella variicola & 1 & 1 & 1 & 1 & - & 1 & - & - & - \\
\hline $\begin{array}{c}\text { Raoutella } \\
\text { ornithinolytica }\end{array}$ & 3 & - & - & 2 & 1 & 1 & - & 2 & - \\
\hline \multicolumn{10}{|l|}{ Yeasts } \\
\hline $\begin{array}{l}\text { Meyerozyma } \\
\text { guilliermondii }\end{array}$ & 6 & 1 & - & 3 & - & 1 & - & 2 & - \\
\hline Candida pararugosa & 3 & - & - & 2 & - & 2 & - & - & - \\
\hline Candida sp. & 1 & - & - & 1 & - & 1 & - & - & - \\
\hline $\begin{array}{l}\text { Rhodotorula } \\
\text { mucilaginosa }\end{array}$ & 1 & - & - & 1 & - & 1 & - & - & - \\
\hline Trichosporon sp. & 2 & - & - & 2 & - & 1 & - & 1 & - \\
\hline $\begin{array}{c}\text { Total } \\
\text { microorganisms }\end{array}$ & 71 & 43 & 6 & 36 & 13 & 34 & 0 & 11 & 0 \\
\hline
\end{tabular}

${ }^{\mathrm{a}}$ Number of total isolates for each genus and/or species. ${ }^{\mathrm{b}}$ Temperature used. ${ }^{\mathrm{c}}$ Lactose fermentation. ${ }^{\mathrm{d}}$ No isolate positive for this test, at this temperature.

Most microbiological research involving Colonial cheese has been directed towards the detection of pathogens, the study of lactic acid or coliform bacterial activity (Carvalho et al, 2019; Pegoraro et al., 2020; Grecellé et al., 2020; Pereira et al., 2017; Zaffari et al., 2007). Some bacterial species have already been 
identified in ready-to-eat Colonial cheese in these studies, such as Staphylococcus spp. (S. aureus, S. epidermidis, S. equorum, S. intermedius, S. haemolyticus, S. saprophyticus, S. sciuri. S. warneri, S. xylosus), Listeria spp. (L. grayi, L. welshimeri, L. monocytogenes) and Escherichia coli. The first study for identifying the microbial composition of Colonial cheese was carried out by Kamimura et al. (2019) using metagenomics, where they observed the predominance of the genera Lactococcus, Lactobacillus and Leuconostoc. Of the 10 bacterial species identified in the present study, four of them had not yet been found in Colonial cheese microbiota (B. cereus, P. humicus, K. variicola and R. ornithinolytica).

None of the yeast genera identified had been previously reported in Colonial cheese. The species M. guilliermondii was the most isolated one (Table 1). Yeasts are often part of the cheese microbiota due to their ability to survive in unfavorable conditions and to metabolize milk constituents. These microorganisms play a significant role in the ripening of some varieties of cheese and, under poor hygiene conditions, in the spoiling of products (Irlinger \& Mounier, 2009). Some Candida sp., Trichosporon sp. and R. mucilaginosa strains had also been isolated in fresh cheese and involved in spoilage (Garnier et al., 2017). However, they have also been observed to be part of the cheese microbiota unrelated to loss of quality (Togay et al., 2020; Cardoso et al., 2015). Among the positive effects of yeasts in cheese production, the development of cheese flavor and texture is well recognized. These effects are related to the ability to ferment lactose, produce aromatic compounds and to the proteolytic and lipolytic capacity (Agarbati et al., 2021; Biagiotti et al., 2018). Most of the identified isolates hydrolyzed lipids at mesophile temperature, and no activity was observed at refrigerated conditions (Table 2). Some yeast species are being studied to be used as starters, as potential probiotic activity in the human intestine, or to limit the growth of undesired microorganisms (Agarbati et al., 2021; Togay et al., 2020; Helmy et al., 2019).

At $30{ }^{\circ} \mathrm{C}, 69 \%$ of the yeast isolates demonstrated lipolytic activity (Table 2). Proteolytic activity was observed in only one of the strains. Lactose fermentation was identified in $23 \%$ of the strains. As it has been observed that yeast present in cheese could help lower the fat and cholesterol levels in people consuming them, perhaps the lipolytic activity observed in many isolates (bacteria and yeast) could have the same effect (Robinson et al., 2021; Zheng et al., 2015). Other authors observed lipolytic activity in several cheese isolated yeasts, such as: Candida sp.; Debaryomyces sp., Galactomyces sp., Kluyveromyces sp., Kodamaea sp., Meyerozyma sp., Pichia sp., Saccharomyces sp., Torulaspora sp., Trichosporon sp. and Yarrowia sp. (Atanassova et al., 2016; Cardoso et al., 2015; Golić et al., 2013; Roostita \& Fleet, 1996; Ferreira \& Viljoen 2003; Spanamberg et al., 2004; Fadda et al., 2004). However, some authors could not find proteolytic and lipolytic activity of the identified yeasts depending on the type of cheese (Togay et al., 2020).

The highest lytic activity for bacteria and yeasts occurred at a temperature of $30^{\circ} \mathrm{C}$. This is not surprising as these isolates were obtained from total mesophilic counting. Cheese metatranscriptomic studies confirmed the direct relationship between the increase in temperature and the increase of bacteria expression of protein and lipids enzymes (De Filippis et al., 2016). Bacteria had higher proteolytic activity than yeasts. The bacterial lipolysis and lactose fermentation were lower than those observed for yeasts $(46 \%$ and $17 \%$ respectively). Unlike yeasts, the bacteria showed proteolytic and lipolytic activity at $5{ }^{\circ} \mathrm{C}(12 \%$ and $22 \%$ respectively), although in lower percentages than at $30^{\circ} \mathrm{C}$. This lower activity at $5{ }^{\circ} \mathrm{C}$ is essential for avoiding product changes during storage. This understanding of the lytic activity of microorganisms can be used to select promising functional starters, for example, as was done by Agarbati et al. (2021) with yeasts strains isolated from dairy environment and Pecorino cheese. These authors obtained $75 \%$ of isolates able to hydrolyze at least one substrate (lactose, proteins, and lipids).

No microorganism demonstrated any activity in the Litmus Milk at $5{ }^{\circ} \mathrm{C}$. The species L. lactis (nine isolates) and $S$. saprophyticus (six isolates) had the highest activity in Litmus Milk at $30^{\circ}$. All yeasts presented at least one strain with clot formation in this test. This medium has three components that could be metabolized by the microorganisms: glucose, lactose, and casein (MacFaddin, 2000). When casein is precipitated by microorganisms, the milk coagulates to form a curd, and this was the reaction observed in 33 
of the 34 microorganisms positive in this test. L. lactis is specifically used for this purpose in cheese production. This species was also the microorganism with the highest number of isolates that fermented lactose (test tube). This result was also expected, since the fermentation of lactose by these bacteria used in starter cultures is desired to start the curdling process in the first step in making Colonial cheese (Ávila et al., 2020; Bukvicki et al., 2020; Yang et al., 2019).

Another three isolated species were also able to ferment lactose and break down the casein, and therefore may be responsible for the same deterioration process during maturation depending on their cellular load (C. freundii, P. humicus, M. guilliermondii). Therefore, further studies should be done to assess whether all of these microorganisms affect the organoleptic characteristics of Colonial cheese.

\section{Conclusion}

This was the first report on culture-based microbiota present in Colonial cheese that was not related to hygiene indicators. This study identified same microorganisms likely involved in the maturation of Colonial cheese using their lytic activity. But some of the species associated with poor hygiene were also found and could cause damage if environmental conditions favor their growth. More research is needed on the species involved in Colonial cheese maturation and their influence on it. This study explored a tiny part of the isolated microbiota in Colonial cheese and undoubtedly metagenomics associated to culturomics could increase the number of species identified and assist dairy industries in producing standard organoleptic characteristics and quality in dairy products, and perhaps even improve them.

\section{Acknowledgements}

The authors thank the National Council for Scientific and Technological Development of Brazil (Conselho Nacional de Desenvolvimento Científico e Tecnológico (CNPq)) and Universidade Federal do Rio Grande do Sul (UFRGS) for the Masters scholarship granted to the first author, Priscilla Vieira de Souza.

\section{References}

Agarbati, A., Marini, E., Galli, E., Canonico, L., Ciani, M., \& Comitini, F. (2021). Characterization of wild yeasts isolated from artisan dairies in the Marche region, Italy, for selection of promising functional starters. Food Science and Technology, 139, 110531. http://dx.doi.org/10.1016/j.Iwt.2020.110531

Atanassova, M. R., Fernández-Otero, C., Rodríguez-Alonso, P., Fernández-No, I. C., Garabal, J. I., \& Centeno, J. A. (2016). Characterization of yeasts isolated from artisanal short-ripened cows' cheeses produced in Galicia (NW Spain). Food Microbiology, 53(Pt B), 172-181. PMid:26678145. http://dx.doi.org/10.1016/j.fm.2015.09.012

Ausani, T. C., Lopes, G. V., Costa, E. F., Corbellini, L. G., \& Cardoso, M. (2019). Microbiological quality of colonial cheese sold in Porto Alegre-RS. Semina: Ciências Agrárias, 40(2), 639-650. http://dx.doi.org/10.5433/1679-0359.2019v40n2p639

Ávila, M., Gómez-Torres, N., Gaya, P., \& Garde, S. (2020). Effect of a nisin-producing lactococcal starter on the late blowing defect of cheese caused by Clostridium tyrobutyricum. International Journal of Food Science \& Technology, 55(10), 3343-3349. http://dx.doi.org/10.1111/ijfs.14598

Bates, S. T., Berg-Lyons, D., Caporaso, J. G., Walters, W. A., Knight, R., \& Fierer, N. (2011). Examining the global distribution of dominant archaeal populations in soil. The ISME Journal, 5(5), 908-917. PMid:21085198. http://dx.doi.org/10.1038/ismej.2010.171

Ben-Gigirey, B., Vieites, J. M., Villa, T. G., \& Barros-Velazquez, J. (2000). Characterization of biogenic amine-producing Stenotrophomonas maltophilia strains isolated from white muscle of fresh and frozen albacore tuna. International Journal of Food Microbiology, 57(1-2), 19-31. http://dx.doi.org/10.1016/S0168-1605(00)00240-3

Berthold-Pluta, A., Pluta, A., Garbowska, M., \& Stefańska, I. (2019). Prevalence and toxicity characterization of Bacillus cereus in food products from Poland. Foods, 8(7), 269. PMid:31331094. http://dx.doi.org/10.3390/foods8070269

Biagiotti, C., Ciani, M., Canonico, L., \& Comitini, F. (2018). Occurrence and involvement of yeast biota in ripening of Italian Fossa cheese. European Food Research and Technology, 244(11), 1921-1931. http://dx.doi.org/10.1007/s00217-018-3104-6

Bruker. (2015). Instructions for use: Bruker guide to MALDI sample preparation. Bremen: Bruker Daltonik GmbH. Retrieved in 2020, December 14, from https://www.bruker.com/fileadmin/user_upload/8

PDFDocs/Separations_MassSpectrometry/InstructionForUse/8702557_IFU_Bruker_Guide_MALDI_Sample_Preparation_ Revision_E.pdf 
Bukvicki, D., Siroli, L., D’Alessandro, M., Cosentino, S., Fliss, I., Said, L. B., Hassan, H., Lanciotti, R., \& Patrignani, F. (2020). Unravelling the potential of Lactococcus lactis strains to be used in cheesemaking production as biocontrol agents. Foods, 9(12), 1815. PMid:33297482. http://dx.doi.org/10.3390/foods9121815

Camargo, A. C., Costa, E. A., Fusieger, A., Freitas, R., Nero, L. A., \& Carvalho, A. F. (2021). Microbial shifts through the ripening of the "Entre Serras" Minas artesanal cheese monitored by high-throughput sequencing. Food Research International, 139, 109803. PMid:33509447. http://dx.doi.org/10.1016/j.foodres.2020.109803

Cardoso, V. M., Borelli, B. M., Lara, C. A., Soares, M. A., Pataro, C., Bodevan, E. C., \& Rosa, R. A. (2015). The influence of seasons and ripening time on yeast communities of a traditional Brazilian cheese. Food Research International, 69, 331-340. http://dx.doi.org/10.1016/j.foodres.2014.12.040

Carvalho, M. M., Fariña, L. O., Strongin, D., Ferreira, C. L. L. F., \& De Dea Lindner, J. (2019). Traditional Colonial-type cheese from the south of Brazil: A case to support the new Brazilian laws for artisanal cheese production from raw milk. Journal of Dairy Science, 102(11), 9711-9720. PMid:31447161. http://dx.doi.org/10.3168/jds.2019-16373

De Filippis, F., Genovese, A., Ferranti, P., Gilbert, J. A., \& Ercolini, D. (2016). Metatranscriptomics reveals temperature-driven functional changes in microbiome impacting cheese maturation rate. Scientific Reports, 6(1), 21871. PMid:26911915. http://dx.doi.org/10.1038/srep21871

El-Baradei, G., Delacroix-Buchet, A. S., \& Ogier, J. C. (2007). Biodiversity of bacterial ecosystems in traditional Egyptian Domiati cheese. Applied and Environmental Microbiology, 73(4), 1248-1255. PMid:17189434. http://dx.doi.org/10.1128/AEM.01667-06

Ercolini, D., Frisso, G., Mauriello, G., Salvatore, F., \& Coppola, S. (2008). Microbial diversity in natural whey cultures used for the production of Caciocavallo Silano PDO cheese. International Journal of Food Microbiology, 124(2), 164-170. PMid:18455822. http://dx.doi.org/10.1016/j.ijfoodmicro.2008.03.007

Fadda, M. E., Mossa, V., Pisano, M. B., Deplano, M., \& Cosentino, S. (2004). Occurrence and characterization of yeasts isolated from artisanal Fiore Sardo cheese. International Journal of Food Microbiology, 95(1), 51-59. PMid:15240074. http://dx.doi.org/10.1016/j.ijfoodmicro.2004.02.001

Ferreira, A. D., \& Viljoen, B. C. (2003). Yeasts as adjunct starters in matured cheddar cheese. International Journal of Food Microbiology, 86(1-2), 131-140. PMid:12892928. http://dx.doi.org/10.1016/S0168-1605(03)00252-6

Franco, A. C., Frazzon, J., \& Frazzon, A. P. G. (2016). Characterization of the faecal bacterial community of wild young South American (Arctocephalus australis) and Subantarctic fur seals (Arctocephalus tropicalis). FEMS Microbiology Ecology, 92(3), 18. PMid:26880785

Funck, G. D., Hermanns, G., Vicenzi, R., Schmidt, J. T., Richards, N. S. P. S., Silva, W. P., \& Fiorentini, A. M. (2015). Microbiological and physicochemical characterization of the raw milk and the colonial type cheese from the Northwestern Frontier region of Rio Grande do Sul, Brazil. Revista do Instituto Adolfo Lutz, 74(3), 247-257. Retrieved in 2020, December 14, from http://www.ial.sp.gov.br/resources/insituto-adolfo-lutz/publicacoes/rial/10/rial74_3_completa/pdf/artigosseparados/1659.pdf

Garnier, L., Valence, F., Pawtowski, A., Auhustsinava-Galerne, L., Frotté, N., Baroncelli, R., Deniel, F., Coton, E., \& Mounier, J. (2017). Diversity of spoilage fungi associated with various French dairy products. International Journal of Food Microbiology, 241, 191-197. PMid:27794247. http://dx.doi.org/10.1016/j.ijfoodmicro.2016.10.026

Golić, N., Cadež, N., Terzić-Vidojević, A., Suranská, H., Beganović, J., Lozo, J., Kos, B., Sušković, J., Raspor, P., \& Topisirović, L. (2013). Evaluation of lactic acid bacteria and yeast diversity in traditional white pickled and fresh soft cheeses from the mountain regions of Serbia and lowland regions of Croatia. International Journal of Food Microbiology, 166(2), 294-300. PMid:23973841. http://dx.doi.org/10.1016/j.ijfoodmicro.2013.05.032

Grecellé, C. B. Z., Mascitti, A. K., Silva, L., Lunge, V. R., \& Costa, M. (2020). Characterization of Staphylococcus species isolated in production stages of Brazilian Colonial cheese. Journal of Tropical Pathology, 49, 1-10. http://dx.doi.org/10.5216/rpt.v49i1.60380

Hajjar, R., Ambaraghassi, G., Sebajang, H., Schwenter, F., \& Su, S.-H. (2020). Raoultella ornithinolytica: Emergence and Resistance. Infection and Drug Resistance, 13, 1091-1104. PMid:32346300. http://dx.doi.org/10.2147/IDR.S191387

Helmy, E. A., Soliman, S. A., Abdel-Ghany, T. M., \& Ganash, M. (2019). Evaluation of potentially probiotic attributes of certain dairy yeast isolated from buffalo sweetened Karish cheese. Heliyon, 5(5), e01649. PMid:31193166 http://dx.doi.org/10.1016/j.heliyon.2019.e01649

Irlinger, F., \& Mounier, J. (2009). Microbial interactions in cheese: Implications for cheese quality and safety. Current Opinion in Biotechnology, 20(2), 142-148. PMid:19342218. http://dx.doi.org/10.1016/j.copbio.2009.02.016

Jonnala, B. R. Y., McSweeney, P. L. H., Sheehan, J. J., \& Cotter, P. D. (2018). Sequencing of the Cheese Microbiome and Its Relevance to Industry. Frontiers in Microbiology, 9, 1020. PMid:29875744. http://dx.doi.org/10.3389/fmicb.2018.01020

Kamimura, B. A., De Filippis, F., Sant'Ana, A. S., \& Ercolini, D. (2019). Large-scale mapping of microbial diversity in artisanal Brazilian cheeses. Food Microbiology, 80, 40-49. PMid:30704595. http://dx.doi.org/10.1016/j.fm.2018.12.014

Leroy, F., \& De Vuyst, L. (2004). Lactic acid bacteria as functional starter cultures for the food fermentation industry. Trends in Food Science \& Technology, 15(2), 67-78. http://dx.doi.org/10.1016/j.tifs.2003.09.004

MacFaddin, J. F. (2000). Biochemical tests for identification of medical bacteria. Baltimore: Williams \& Wilkins Company.

Milani, C., Alessandri, G., Mancabelli, L., Lugli, G. A., Longhi, G., Anzalone, R., Viappiani, A., Duranti, S., Turroni, F., Ossiprandi, M. C., van Sinderen, D., \& Ventura, M. (2019). Bifidobacterial Distribution Across Italian Cheeses Produced from Raw Milk. Microorganisms, 7(12), 599. PMid:31766566. http://dx.doi.org/10.3390/microorganisms7120599 
Montel, M. C., Buchin, S., Mallet, A., Delbes-Paus, C., Vuitton, D. A., Desmasures, N., \& Berthier, F. (2014). Traditional cheeses: Rich and diverse microbiota with associated benefits. International Journal of Food Microbiology, 177, $136-154$. PMid:24642348. http://dx.doi.org/10.1016/j.ijfoodmicro.2014.02.019

Osorio-Cadavid, E., Ramírez, M., López, W. A., \& Mambuscay, L. A. (2009). Estandarización de un protocolo sencillo para la extracción de ADN genómico de levaduras. Revista Colombiana de Biotecnologia, 11, 125-131. Retrieved in 2020, December 14, from https://www.researchgate.net/publication/26849648

Pegoraro, K., Sereno, M. J., Cavicchioli, V. Q., Viana, C., Nero, L., \& Bersot, L. D. (2020). Bacteriocinogenic potential of lactic acid bacteria isolated from artisanal colonial type - Cheese. Archives of Veterinary Science, 25(1), 35-44. http://dx.doi.org/10.5380/avs.v25i1.68261

Peláez, C., \& Requena, T. (2005). Exploiting the potential of bacteria in the cheese ecosystem. International Dairy Journal, 15(6-9), 831-844. http://dx.doi.org/10.1016/j.idairyj.2004.12.001

Pereira, E. B., Pozza, M. S. D., Olivo, P. M., Santa, O. D., Pires, S. D., Borsoi, J. A., Costa, P. B., \& Pozza, P. C. (2017). Microbiota indigenous milk, mesophilic lipolytic and proteolytic colonial cheese matured, produced at different times of the year. Revista Brasileira de Saúde e Produção Animal, 18(4), 549-559. http://dx.doi.org/10.1590/s1519-99402017000400006

Pinto, C. L. O., Machado, S. G., Martins, M. L., \& Vanetti, M. C. D. (2015). Identificação de bactérias psicrotróficas proteolíticas isoladas de leite cru refrigerado e caracterização do seu potencial deteriorador. Revista do Instituto de Latícinios Cândido Tostes, 70(2), 105-116. http://dx.doi.org/10.14295/2238-6416.v70i2.401

Ramírez-Castrillón, M., Mendes, S. D. C., Inostroza-Ponta, M., \& Valente, P. (2014). (GTG)5 MSP-PCR fingerprinting as a technique for discrimination of wine associated yeasts? PLoS One, 9(8), e105870. PMid:25171185. http://dx.doi.org/10.1371/journal.pone.0105870

Riyaz-UI-Hassan, S., Verma, V., \& Qazi, G. N. (2008). Evaluation of three different molecular markers for the detection of Staphylococcus aureus by polymerase chain reaction. Food Microbiology, 25(3), 452-459. PMid:18355670. http://dx.doi.org/10.1016/j.fm.2008.01.010

Robinson, R. C., Nielsen, S. D., Dallas, D. C., \& Barile, D. (2021). Can cheese mites, maggots and molds enhance bioactivity? Peptidomic investigation of functional peptides in four traditional cheeses. Food \& Function, 12(2), 633-645. PMid:33346308. http://dx.doi.org/10.1039/D0FO02439B

Rodríguez-Medina, N., Barrios-Camacho, H., Duran-Bedolla, J., \& Garza-Ramos, U. (2019). Klebsiella variicola: An emerging pathogen in humans. Emerging Microbes \& Infections, 8(1), 973-985. PMid:31259664. http://dx.doi.org/10.1080/22221751.2019.1634981

Roostita, R., \& Fleet, G. H. (1996). Growth of yeasts in milk and associated changes to milk composition. International Journal of Food Microbiology, 31(1-3), 205-219. PMid:8880309. http://dx.doi.org/10.1016/0168-1605(96)00999-3

Sáez-Nieto, J., Medina-Pascual, M. J., Carrasco, G., Garrido, N., Fernandez-Torres, M. A., Villalón, P., \& Valdezate, S. (2017). Paenibacillus spp. isolated from human and environmental samples in Spain: Detection of 11 new species. New Microbes and New Infections, 19, 19-27. PMid:28702198. http://dx.doi.org/10.1016/j.nmni.2017.05.006

Schleifer, K.-H. (2009). Phylum XIII. Firmicutes Gibbons and Murray 1978, 5 (Firmacutes [sic] Gibbons and Murray 1978, 5). In P. Vos, G. Garrity, D. Jones, N. R. Krieg, W. Ludwig, F. A. Rainey \& W. Whitman (Eds.), Bergey's manual of systematic bacteriology: Volume 3: The firmicutes (2nd ed., pp. 414-416). New York: Springer-Verlag.

Spanamberg, A., Hartfelder, C., Fuentefria, A. M., \& Valente, P. (2004). Diversity and enzyme production by yeasts isolated from raw milk in southern Brazil. Acta Scientiae Veterinariae, 32(3), 195-199. http://dx.doi.org/10.22456/1679-9216.16897

Teider Júnior, P. I., Ribeiro Júnior, J. C., Ossugui, E. H., Tamanini, R., Ribeiro, J., Santos, G. A., Alfieri, A. A., \& Beloti, V. (2019). Pseudomonas spp. and other psychrotrophic microorganisms in inspected and non-inspected Brazilian Minas Frescal cheese: Proteolytic, lipolytic and AprX production potential. Pesquisa Veterinária Brasileira, 39(10), 807-815. http://dx.doi.org/10.1590/1678-5150-pvb-6037

Tilocca, B., Costanzo, N., Morittu, V. M., Spina, A. A., Soggiu, A., Britti, D., Roncada, P., \& Piras, C. (2020). Milk microbiota: Characterization methods and role in cheese production. Journal of Proteomics, 210, 103534. PMid:31629058. http://dx.doi.org/10.1016/j.jprot.2019.103534

Togay, S. O., Capce, A., Siesto, G., Aksu, H., Sandikci Altunatmaz, S., Yilmaz Aksu, F., Romano, P., \& Karagul Yuceer, Y. (2020). Molecular characterization of yeasts isolated from traditional Turkish cheeses. Food Science and Technology, 40(4), 871-876. http://dx.doi.org/10.1590/fst.24319

White, T., Burns, T., Lee, S., \& Taylor, J. (1990). Amplification and direct sequencing of fungal ribosomal RNA genes for phylogenetics. In M. A. Innis, D. H. Gelfand, J. J. Sninsky \& T. J. White (Eds.), PCR protocols: A guide to methods and applications (pp. 315-322). San Diego: Academic Press.

Wieser, A., Schneider, L., Jung, J., \& Schubert, S. (2012). MALDI-TOF MS in microbiological diagnostics: Identification of microorganisms and beyond (mini review). Applied Microbiology and Biotechnology, 93(3), 965-974. PMid:22198716. http://dx.doi.org/10.1007/s00253-011-3783-4

Yang, Y., Li, N., Jiang, Y., Liu, Z., Liu, X., Zhao, J., Zhang, H., \& Chen, W. (2019). Enzymatic perspective of galactosidases reveals variations in lactose metabolism among Lactococcus lactis strains. Journal of Dairy Science, 102(7), 6027-6031. PMid:31056324. http://dx.doi.org/10.3168/jds.2018-15973

Zaffari, C. B., Mello, J. F., \& Costa, M. (2007). Qualidade bacteriológica de queijos artesanais comercializados em estradas do litoral norte do Rio Grande do Sul, Brasil. Ciência Rural, 37(3), 862-867. http://dx.doi.org/10.1590/S0103-84782007000300040 
Zheng, H., Yde, C. C., Clausen, M. R., Kristensen, M., Lorenzen, J., Astrup, A., \& Bertram, H. C. (2015). Metabolomics investigation to shed light on cheese as a possible piece in the French paradox puzzle. Journal of Agricultural and Food Chemistry, 63(10), 2830-9. PMid:25727903. http://dx.doi.org/10.1021/jf505878a

Funding: National Council for Scientific and Technological Development of Brazil and Universidade Federal do Rio Grande do Sul (UFRGS). 